medRxiv preprint doi: https://doi.org/10.1101/2020.03.05.20031054; this version posted March 6, 2020. The copyright holder for this preprint (which was not certified by peer review) is the author/funder, who has granted medRxiv a license to display the preprint in perpetuity.

It is made available under a CC-BY-NC-ND 4.0 International license .

\title{
Prediction of Venous Thromboembolism Based on Clinical and Genetic Factors
}

David A. Kolin, M.Sc. ${ }^{* 1,2}$, Scott Kulm, B.Eng. ${ }^{* 1,2}$, and Olivier Elemento, Ph.D. ${ }^{1,2}$

*Mr. Kolin and Kulm contributed equally to this article.

${ }^{1}$ Caryl and Israel Englander Institute for Precision Medicine, The Meyer Cancer Center, Weill

Cornell Medicine, New York, NY, USA

${ }^{2}$ Physiology and Biophysics Systems Biology, Weill Cornell Medicine, New York, NY, USA

Correspondence: Olivier Elemento, Caryl and Israel Englander Institute for Precision Medicine, The Meyer Cancer Center, Weill Cornell Medicine, New York, NY, USA 
medRxiv preprint doi: https://doi.org/10.1101/2020.03.05.20031054; this version posted March 6, 2020. The copyright holder for this preprint (which was not certified by peer review) is the author/funder, who has granted medRxiv a license to display the preprint in perpetuity.

It is made available under a CC-BY-NC-ND 4.0 International license .

BACKGROUND: Both clinical and genetic factors drive the risk of venous thromboembolism. However, whether clinically recorded risk factors and genetic variants can be combined into a clinically applicable predictive score remains unknown.

METHODS: Using Cox proportional-hazard models, we analyzed the association of risk factors with the likelihood of venous thromboembolism in U.K. Biobank, a large prospective cohort. We created a novel ten point clinical score using seven established clinical risk factors for venous thromboembolism. We also generated a polygenic risk score of 21 single nucleotide polymorphisms to quantify genetic risk. The genetic score was categorized into high risk (top two deciles of scores), intermediate risk (deciles three to eight), and low risk (lowest two deciles). The discrete clinical score led to the following approximate decile categorizations: high risk ( 5 to 10 points), intermediate risk ( 3 to 4 points), and low risk (0 to 2 points).

RESULTS: Amongst the 502,536 participants in the U.K. Biobank, there were 4,843 events of venous thromboembolism. Analyses of established clinical risk factors and the most commonly used medications revealed that participants were at decreased risk of venous thromboembolism if they had ever used oral contraceptive pills (hazard ratio, $0.88 ; 95 \%$ confidence interval [CI], 0.79 to 0.99 ) or if they currently used bendroflumethiazide (hazard ratio, $0.84 ; 95 \% \mathrm{CI}, 0.74$ to 0.95 ), cod liver oil capsules (hazard ratio, $0.87 ; 95 \% \mathrm{CI}, 0.77$ to 0.99 ), or atenolol (hazard ratio, $0.79 ; 95 \% \mathrm{CI}, 0.68$ to 0.91). Participants were at significantly increased risk of venous thromboembolism if they were at high clinical risk (hazard ratio, 5.98; 95\% CI, 5.43 to 6.59) or high genetic risk (hazard ratio, 2.28; $95 \%$ CI, 2.07 to 2.51 ) relative to participants at low clinical or genetic risk, respectively. Combining clinical risk factors with genetic risk factors produced a model that better predicted risk of venous thromboembolism than either model alone $(\mathrm{P}<0.001)$. Participants at high clinical and genetic risk in the combined score had over an eightfold increased risk of venous thromboembolism relative to participants at low risk (hazard ratio, 8.27 ; $95 \%$ CI 7.59 to 9.00 ).

CONCLUSIONS: By assessing venous thromboembolic events in over 500,000 participants, we identified several known and novel associations between risk factors and venous thromboembolism. Participants in the high risk group of a combined score, consisting of clinical and genetic factors, were over eight times more likely to experience venous thromboembolism than participants in the low risk group. 
medRxiv preprint doi: https://doi.org/10.1101/2020.03.05.20031054; this version posted March 6, 2020. The copyright holder for this preprint (which was not certified by peer review) is the author/funder, who has granted medRxiv a license to display the preprint in perpetuity.

It is made available under a CC-BY-NC-ND 4.0 International license .

\section{INTRODUCTION}

Both clinical and genetic factors drive the likelihood of venous thromboembolism, the leading cause of preventable hospital deaths. ${ }^{1}$ Considerable evidence demonstrates that individuals exposed to clinical risk factors, such as cigarette smoke, cancer, oral contraceptive pills, high body mass index, recent hospitalization, and major surgery, have markedly increased risk of venous thromboembolism. ${ }^{2-7}$

While clinical factors account for a significant proportion of thromboembolic risk, over $60 \%$ of variation in the risk of venous thromboembolism can be attributed to genetic factors. ${ }^{8}$ Factor $\mathrm{V}$ Leiden and Factor II Mutation, two monogenic variants, were first described in the 1990 s. $^{9-14}$ Since then, genome-wide association studies have identified over 20 additional loci ${ }^{15-19}$ Risk alleles, when combined into a polygenic score, are capable of quantifying genetic susceptibility and are often more effective at predicting risk than rare monogenic variants alone. ${ }^{20-27}$

Currently, our understanding of clinical and genetic risk for venous thromboembolism guides both prophylaxis and treatment. ${ }^{28-31}$ In acute care settings, clinical scores, such as the Wells Score and Geneva Score, can rapidly quantify risk of venous thromboembolism. Genetic susceptibility to venous thromboembolism can be ascertained by detecting specific point mutations known to cause inherited thrombophilias. However, a quantitative scoring system - consisting of clinical and genetic factors - that predicts the likelihood of venous thromboembolic events prior to hospitalization has not yet been established. In order to address these gaps, we first explored clinical risk factors for venous thromboembolism in U.K. Biobank, a large longitudinal cohort. We then determined the extent to which clinical and genetic factors, both individually and combined, predispose individuals to venous thromboembolism. 
medRxiv preprint doi: https://doi.org/10.1101/2020.03.05.20031054; this version posted March 6, 2020. The copyright holder for this preprint

(which was not certified by peer review) is the author/funder, who has granted medRxiv a license to display the preprint in perpetuity.

It is made available under a CC-BY-NC-ND 4.0 International license .

\section{METHODS}

\section{Study Population}

The U.K. Biobank is a prospective cohort of 502,536 participants between the ages of 40 and 69 years recruited from across the United Kingdom from 2006 to 2010. Baseline information was gathered during an in-person interview, and in-patient health outcome data were collected prospectively for all hospital episodes. For this study, all U.K. Biobank participants were included in analyses of clinical risk factors. For the polygenic risk score analyses, 131,194 participants were included in score derivation, and 276,988 participants were included in model assessment. Written informed consent was obtained for all of the participants in U.K. Biobank.

\section{Study Outcome}

The study outcome was any primary venous thromboembolism event, including portal vein thrombosis, thrombophlebitis migrans, pulmonary embolism, combined phlebitis thrombophlebitis, and embolism and thrombosis of other veins. Additional details regarding the coding of venous thromboembolism events are provided in Table S1 in the Supplementary Appendix, available with the full text of this article at NEJM.org. Participants were considered at risk for venous thromboembolism at baseline and were censored at death, loss to follow-up, or the last date of hospital admission (March 31, 2017 for England, October 31, 2016 for Scotland, and February 29, 2016 for Wales).

\section{Polygenic Risk Score}

We constructed a polygenic risk score from 21 single nucleotide polymorphisms (SNPs), all with genome-wide significance in previously published genome wide association studies of venous thromboembolism. ${ }^{15,16,18,19,32}$ To determine which studies and SNPs to include in the polygenic score, a forward stepwise selection method, considering both dominance effects and genetic interactions, was developed. Variable strength amongst studies was measured by the effect sizes, generated from a logistic regression of all study specific scores. The polygenic score was then constructed from the selected SNPs by summing the product of each participant's number of alleles, the study-derived effect size, and a derived multiplier representing the strength of each study. Logistic regression analyses employed in the derivation of the polygenic risk score were adjusted for basic covariates: the first four principal components of ancestry, the genotyping array, age, and sex. Details of the included studies and the genotyping platform used are provided in Table S2 in the Supplementary Appendix.

\section{Statistical Analysis}

We tested the association between eleven established risk factors and incident venous thromboembolism events using Cox proportional-hazard models. In order to better understand the association of potential risk factors with venous thromboembolism, we also conducted four additional analyses of the ten most common cancer subtypes, medications, non-cancer illnesses, and fracture sites using Cox proportional-hazard models. Primary Cox proportional-hazard models were adjusted for age, sex, body mass index (BMI), previous cancer diagnosis, smoking status, alcohol intake frequency, use of oral contraceptive pills, use of hormone replacement therapy, fracture in the last five years, previous deep vein thrombosis, previous pulmonary embolism, and the first four principal components of ancestry. 
medRxiv preprint doi: https://doi.org/10.1101/2020.03.05.20031054; this version posted March 6, 2020. The copyright holder for this preprint (which was not certified by peer review) is the author/funder, who has granted medRxiv a license to display the preprint in perpetuity.

It is made available under a CC-BY-NC-ND 4.0 International license.

Next, we created three novel scores for venous thromboembolism: a clinical risk score, a genetic risk score (based on polygenic risk), and a combined score. We created a ten point clinical risk score using seven established risk factors for venous thromboembolism: sex, age, BMI, smoking status, fracture in the last five years, previous cancer diagnosis, and previous venous thromboembolism (deep vein thrombosis or pulmonary embolism) (Table S3 in the Supplementary Appendix). After creating a genetic risk score based on polygenic risk, the clinical and genetic scores were combined into a single score by adding each score proportional to their hazard ratios, derived from a training set.

The genetic and combined score were then used to categorize study participants into three risk categories: low risk (lowest two deciles), intermediate risk (deciles three to eight), and high risk (top two deciles). The discrete ten point clinical score led to approximate decile categorizations as follows: high risk ( 5 to 10 points), intermediate risk ( 3 to 4 points), and low risk ( 0 to 2 points) (Table S4 in the Supplementary Appendix). These categories were used with Cox proportionalhazard models to calculate hazard ratios, 10-year event rates, and Kaplan-Meier estimators. The fit of each model was measured by using concordance for Cox proportional-hazard models and area under the curve (AUC) for logistic regression models. All of the analyses were performed with the use of R software, version 3.5 (R Project for Statistical Computing). 
medRxiv preprint doi: https://doi.org/10.1101/2020.03.05.20031054; this version posted March 6, 2020. The copyright holder for this preprint (which was not certified by peer review) is the author/funder, who has granted medRxiv a license to display the preprint in perpetuity. It is made available under a CC-BY-NC-ND 4.0 International license .

\section{RESULTS}

\section{Participant Characteristics and Established Risk Factors}

There were a total of 4,843 venous thromboembolic events amongst the 502,536 participants in U.K. Biobank. The mean age of participants was 56.5 years, and $54.4 \%$ of participants were female (Table S5 in the Supplementary Appendix). At baseline, 220,446 (80.6\%) women reported ever taking an oral contraceptive pill. 9,323 (1.8\%) participants had a previous deep vein thrombosis, and 3,955 $(0.8 \%)$ participants had a previous pulmonary embolism.

We examined 11 known risk factors for venous thromboembolism using multivariate Coxproportional hazard models. Class 3 obesity (BMI $\geq 40 \mathrm{~kg} / \mathrm{m}^{2}$ ), relative to normal weight, was one of two risk factors associated with over a threefold increase in the risk of venous thromboembolism (hazard ratio, 3.30; 95\% confidence interval [CI], 2.81 to 3.88) (Fig. 1). Previous deep vein thrombosis was the only other risk factor associated with over a threefold increase in risk (hazard ratio, 3.34; 95\% CI, 2.96 to 3.77). Perhaps surprisingly, participants who had ever used oral contraception had a $12 \%$ decreased risk of venous thromboembolism (hazard ratio, $0.88 ; 95 \% \mathrm{CI}$, 0.79 to 0.99 ). In exploratory analyses of the length of use of contraception, we found that women who used contraception for at least twenty years were also at decreased risk of venous thromboembolism (hazard ratio, 0.81; 95\% CI, 0.67 to 0.98) (Table S6 in the Supplementary Appendix). However, an insignificant trend of venous thromboembolism risk was observed when length of oral contraceptive use was analyzed on a continuous scale $(\mathrm{P}=0.29)$. Further analyses revealed that, of the 4,919 current users of oral contraceptive pills, 935 were taking desogestrel (Cerazette 75 microgram tablets) (Table S7 in the Supplementary Appendix). Compared to fully adjusted Cox-proportional hazard models, univariate risk ratios of death from venous thromboembolism identified similar patterns in risk (Fig. S1 and Table S8 in the Supplementary Appendix).

\section{Cancer Subtypes, Medications, Non-Cancer Illnesses, and Fracture Sites}

In order to better understand the specific clinical risk factors associated with risk of venous thromboembolism, we also analyzed the association of common cancer subtypes, medications, noncancer illnesses, and fracture sites with venous thromboembolic risk. Previously diagnosed breast cancer, prostate cancer, colon cancer, and cervical cancer were associated with increased risk of venous thromboembolism (Fig. 2). Of the ten most common medications in U.K. Biobank, three were associated with a decreased risk of venous thromboembolism and one was associated with increased risk. Hazard ratios for bendroflumethiazide and atenolol were 0.84 (95\% CI, 0.74 to 0.95 ) and 0.79 (95\% CI, 0.68 to 0.91 ), respectively, and there was some evidence that use of cod liver oil capsules was associated with a decreased risk of venous thromboembolism (hazard ratio, 0.87; 95\% CI, 0.77 to 0.99 ). Amitriptyline was the only medication associated with an increased risk of venous thromboembolism (hazard ratio, $1.23 ; 95 \%$ CI, 1.02 to 1.48 ). Participants with asthma were at $16 \%$ increased risk of venous thromboembolism, while those with either osteoarthritis or depression were at $18 \%$ increased risk of experiencing a venous thromboembolic event. Hypercholesterolemia was associated with an 8\% decreased risk of venous thromboembolism (hazard ratio, $0.92 ; 95 \% \mathrm{CI}, 0.84$ to 1.00 ), and diabetes was associated with a $20 \%$ decreased risk of venous thromboembolism (hazard ratio, $0.80 ; 95 \%$ CI, 0.70 to 0.92 ). However, evidence of any association disappeared with adjustment for common therapies for hypercholesterolemia or diabetes (Table S9 in the Supplementary Appendix). Of the participants who fractured a bone in the last five years, only participants who fractured their wrist or unspecified bones had significantly increased risk of venous thromboembolic 
medRxiv preprint doi: https://doi.org/10.1101/2020.03.05.20031054; this version posted March 6, 2020. The copyright holder for this preprint (which was not certified by peer review) is the author/funder, who has granted medRxiv a license to display the preprint in perpetuity. It is made available under a CC-BY-NC-ND 4.0 International license .

events. We found that analyses with minimally adjusted models generated similar results (Fig. S2 through S6 in the Supplementary Appendix).

\section{Model Creation}

We compared nested Cox proportional-hazard and logistic regression models of the clinical, genetic, and combined scores in order to determine whether the addition of covariates improved the predictive abilities of our models. The Cox proportional-hazard model adjusted for basic covariates alone generated a concordance of 0.63 (95\% CI, 0.62 to 0.64 ) (Figure 3). A model with the clinical risk score, adjusted for the first four principal components of ancestry and genotyping array, improved concordance to 0.68 (95\% CI, 0.66 to 0.69). Similarly, a model with the genetic score, adjusted for the basic covariates, improved concordance relative to the basic model alone (concordance, $0.67 ; 95 \% \mathrm{CI}, 0.66$ to 0.69 ). The odds ratio for participants in the top polygenic risk score percentile compared to the bottom 99 percentiles was 5.33 (95\% CI, 5.32 to 5.34), and polygenic risk increased significantly with the number of venous thromboembolic events (Fig. S7 and S8 in the Supplementary Appendix). The combined score, adjusted for the first four principal components of ancestry and the sequencing array, generated a concordance of 0.71 (95\% CI, 0.70 to $0.72)$, significantly higher than either previous model alone $(\mathrm{P}<0.001)$. Equivalent analyses with logistic regression generated an AUC of 0.70 (95\% CI, 0.69 to 0.71). Cross validation of logistic regressions and bootstrap analyses of the Cox proportional-hazard models led to comparable results. Additional analyses showed an absence of additional interactions or clustering (Fig. S9 to S13 in the Supplementary Appendix).

\section{Risk Stratification}

Clinical, genetic and combined scores were used to stratify risk by comparing participants at low, intermediate, and high risk. Participants at high clinical or high genetic risk had $498 \%$ (hazard ratio, 5.98; 95\% CI 5.43 to 6.59) and 128\% (hazard ratio, 2.28; 95\% CI 2.07 to 2.51) increased risk of venous thromboembolism, respectively, relative to participants at low clinical or low genetic risk. Participants at high genetic risk yet low clinical risk had an $80 \%$ (hazard ratio, $0.20 ; 95 \%$ CI 0.17 to 0.23) decreased risk of venous thromboembolism compared to participants at high genetic and high clinical risk, suggesting that clinical factors can attenuate genetic predispositions. Alternatively, participants at high clinical and genetic risk had over a twofold (hazard ratio, 2.09; 95\% CI, 1.66 to 2.65 ) increased risk of venous thromboembolism compared to participants at high clinical yet low genetic risk, indicating the added benefits of accounting for genetic factors. For the combined score, participants in the high risk group were at over an eightfold (hazard ratio, 8.27; 95\% CI 7.59 to 9.00) increased risk of venous thromboembolism relative to participants in the low risk group (Fig. S14 in the Supplementary Appendix). When the clinical score and genetic score were analyzed independently, participants at both high clinical and genetic risk, $2.7 \%$ of the total population, had over thirteen-fold (hazard ratio, 13.87 ; 95\% CI 11.22 to 17.13 ) greater risk of venous thromboembolism than participants at both low clinical and genetic risk (Figure 4). The 10-year event rate was $4.89 \%$ for participants at high clinical and genetic risk, and $0.37 \%$ for participants at low clinical and genetic risk. 
medRxiv preprint doi: https://doi.org/10.1101/2020.03.05.20031054; this version posted March 6, 2020. The copyright holder for this preprint

(which was not certified by peer review) is the author/funder, who has granted medRxiv a license to display the preprint in perpetuity.

It is made available under a CC-BY-NC-ND 4.0 International license .

\section{DISCUSSION}

In this study, we quantified the risk of venous thromboembolism by examining both clinical and genetic risk factors in U.K. Biobank, a large prospective cohort of over 500,000 participants. We found several noteworthy associations, and we subsequently derived a novel risk score that combines both clinical and genetic factors. Our findings support four conclusions.

First, in analyses of clinical risk factors, we found that participants who had ever used oral contraceptives were at decreased risk of venous thromboembolism (hazard ratio, 0.88). This finding is in direct contrast to the well-described increased risk of venous thromboembolism with oral contraceptive use. ${ }^{33}$ The reasons for this finding are likely multifold. Importantly, while the majority of women had reported ever using oral contraceptive pills, most women had discontinued use by the start of the study. Furthermore, the mean age of participants in our cohort at baseline was over 56 years, suggesting that women who had ever used oral contraceptive pills were decades past the highrisk period for venous thromboembolism that occurs during the first months of oral contraceptive use. Finally, due to contraindications, participants with severe thrombophilias likely did not use oral contraceptive pills.

Second, analyses of the most common cancer subtypes, medications, non-cancer illnesses, and fracture sites identified several associations. The decreased risk of venous thromboembolism with use of atenolol may be due to lower levels of circulating coagulation factors. ${ }^{34}$ While the reduced risk of venous thromboembolism with use of cod liver oil capsules has been reported previously, to the best of our knowledge, use of bendroflumethiazide has not been associated with a decreased risk of venous thromboembolism. ${ }^{35,36}$ While it is plausible that glucocorticoid and antidepressant use contribute to our findings that asthma, osteoarthritis, and depression are associated with increased risk of venous thromboembolism, accounting for common disease-specific medications does not reduce the likelihood of venous thromboembolism considerably. Alternatively, we provide evidence that the apparent protective effects of hypercholesterolemia and diabetes in this cohort are likely due to use of disease-specific therapies.

Third, combining clinical and genetic factors into a single combined score yielded a predictive model with accuracy similar to that of other scoring systems currently used in clinical settings (AUC, 0.70; concordance, 0.71). For example, the Wells Score and Geneva Score, two scores frequently used to assess short-term risk of pulmonary embolism, have reported AUCs ranging from approximately 0.68 to 0.85 and 0.64 to 0.76 , respectively. ${ }^{37-40}$ While both the Wells Score and Geneva Score evaluate risk in hospitalized patients, the combined clinical and genetic score presented herein provides a means to estimate risk of venous thromboembolism in individuals who are not hospitalized.

Fourth, the ability of a clinical risk score for venous thromboembolism to stratify participants into different risk groups is improved by the addition of a polygenic risk score. Even after participants are categorized according to their clinical risk, by using seven major risk factors for venous thromboembolism, a polygenic risk score allows for further categorization of participants into significantly different risk groups. These data indicate that genetic risk factors are powerful modulators of susceptibility to venous thromboembolism, and our results suggest that adoption of polygenic risk scores in the clinic may improve venous thromboembolism prediction and prophylaxis.

Our study has several limitations. First, although we attempted to control for confounding through multivariate modeling including fifteen covariates, residual confounding still remains, from variables such as immobility and diet. Second, this study relied on a single cohort of primarily Caucasian participants, and the relative homogeneity of U.K. Biobank - derived from a population of participants from the United Kingdom - may have resulted in models that overestimate the true predictive power of our scoring system. Third, the duration of this prospective study was slightly 
medRxiv preprint doi: https://doi.org/10.1101/2020.03.05.20031054; this version posted March 6, 2020. The copyright holder for this preprint (which was not certified by peer review) is the author/funder, who has granted medRxiv a license to display the preprint in perpetuity.

It is made available under a CC-BY-NC-ND 4.0 International license.

greater than ten years, a time frame which may underestimate the true predictive power of the clinical and genetic risk scores.

In conclusion, analysis of thromboembolic events in over 500,000 participants identified several known and novel associations. Furthermore, synergistically combining genetic and clinical risk factors into a single combined score identified that participants in the top two deciles of the score were at over eightfold increased risk of venous thromboembolism relative to participants in the lowest two deciles. 
medRxiv preprint doi: https://doi.org/10.1101/2020.03.05.20031054; this version posted March 6, 2020. The copyright holder for this preprint (which was not certified by peer review) is the author/funder, who has granted medRxiv a license to display the preprint in perpetuity.

It is made available under a CC-BY-NC-ND 4.0 International license .

\section{References}

1. The Lancet Haematology. Thromboembolism: an under appreciated cause of death. The Lancet Haematology 2015;2(10):e393.

2. Di Nisio M, van Es N, Büller HR. Deep vein thrombosis and pulmonary embolism. The Lancet 2016;388(10063):3060-73.

3. Nemeth B, Lijfering WM, Nelissen RGHH, et al. Risk and Risk Factors Associated With Recurrent Venous Thromboembolism Following Surgery in Patients With History of Venous Thromboembolism. JAMA Network Open 2019;2(5):e193690.

4. Gregson J, Kaptoge S, Bolton T, et al. Cardiovascular Risk Factors Associated With Venous Thromboembolism. JAMA Cardiology 2019;4(2):163.

5. Anderson FA. Risk Factors for Venous Thromboembolism. Circulation 2003;107(90231):9I--16.

6. White RH. The Epidemiology of Venous Thromboembolism. Circulation 2003;107(90231):4I-8.

7. Tsai AW, Cushman M, Rosamond WD, Heckbert SR, Polak JF, Folsom AR. Cardiovascular Risk Factors and Venous Thromboembolism Incidence: The Longitudinal Investigation of Thromboembolism Etiology. Archives of Internal Medicine 2002;162(10):1182.

8. Souto JC, Almasy L, Borrell M, et al. Genetic susceptibility to thrombosis and its relationship to physiological risk factors: the GAIT study. Genetic Analysis of Idiopathic Thrombophilia. Am J Hum Genet 2000;67(6):1452-9.

9. Rees DC, Cox M, Clegg JB. World distribution of factor V Leiden. The Lancet 1995;346(8983):1133-4. 
medRxiv preprint doi: https://doi.org/10.1101/2020.03.05.20031054; this version posted March 6, 2020. The copyright holder for this preprint (which was not certified by peer review) is the author/funder, who has granted medRxiv a license to display the preprint in perpetuity.

It is made available under a CC-BY-NC-ND 4.0 International license .

10. Lalouschek W, Aull S, Series W, Zeiler K, Mannhalter C. The prothrombin G20210A mutation and factor V Leiden mutation in patients with cerebrovascular disease. Blood 1998;92(2):704-5.

11. Bertina RM, Koeleman BPC, Koster T, et al. Mutation in blood coagulation factor V associated with resistance to activated protein C. Nature 1994;369(6475):64-7.

12. Watzke HH, Schüttrumpf J, Graf S, Huber K, Panzer S. Increased prevalence of a polymorphism in the gene coding for human prothrombin in patients with coronary heart disease. Thrombosis Research 1997;87(6):521-6.

13. Campello E, Spiezia L, Simioni P. Diagnosis and management of factor V Leiden. Expert Review of Hematology 2016;9(12):1139-49.

14. Poort SR, Rosendaal FR, Reitsma PH, Bertina RM. A common genetic variation in the 3'untranslated region of the prothrombin gene is associated with elevated plasma prothrombin levels and an increase in venous thrombosis. Blood 1996;88(10):3698-703.

15. Tang W, Teichert M, Chasman DI, et al. A genome-wide association study for venous thromboembolism: the extended cohorts for heart and aging research in genomic epidemiology (CHARGE) consortium. Genet Epidemiol 2013;37(5):512-21.

16. Heit JA, Armasu SM, Asmann YW, et al. A genome-wide association study of venous thromboembolism identifies risk variants in chromosomes 1q24.2 and 9q. J Thromb Haemost 2012;10(8):1521-31.

17. Germain M, Saut N, Greliche N, et al. Genetics of Venous Thrombosis: Insights from a New Genome Wide Association Study. PLOS ONE 2011;6(9):e25581. 
medRxiv preprint doi: https://doi.org/10.1101/2020.03.05.20031054; this version posted March 6, 2020. The copyright holder for this preprint (which was not certified by peer review) is the author/funder, who has granted medRxiv a license to display the preprint in perpetuity.

It is made available under a CC-BY-NC-ND 4.0 International license .

18. Germain M, Chasman DI, de Haan H, et al. Meta-analysis of 65,734 individuals identifies TSPAN15 and SLC44A2 as two susceptibility loci for venous thromboembolism. Am J Hum Genet 2015;96(4):532-42.

19. Hinds DA, Buil A, Ziemek D, et al. Genome-wide association analysis of self-reported events in 6135 individuals and 252827 controls identifies 8 loci associated with thrombosis. Human Molecular Genetics 2016;25(9):1867-74.

20. Emdin CA, Khera AV, Natarajan P, et al. Genetic Association of Waist-to-Hip Ratio With Cardiometabolic Traits, Type 2 Diabetes, and Coronary Heart Disease. JAMA 2017;317(6):626.

21. Khera AV, Emdin CA, Drake I, et al. Genetic Risk, Adherence to a Healthy Lifestyle, and Coronary Disease. New England Journal of Medicine 2016;375(24):2349-58.

22. Soria JM, Morange P, Vila J, et al. Multilocus Genetic Risk Scores for Venous Thromboembolism Risk Assessment. Journal of the American Heart Association [Internet] 2014 [cited 2019 Aug 21];3(5). Available from: https://www.ahajournals.org/doi/10.1161/JAHA.114.001060

23. Fuchsberger C, Flannick J, Teslovich TM, et al. The genetic architecture of type 2 diabetes. Nature 2016;536(7614):41-7.

24. Niemi MEK, Martin HC, Rice DL, et al. Common genetic variants contribute to risk of rare severe neurodevelopmental disorders. Nature 2018;562(7726):268-71.

25. Huyghe JR, Bien SA, Harrison TA, et al. Discovery of common and rare genetic risk variants for colorectal cancer. Nature Genetics 2019;51(1):76-87. 
medRxiv preprint doi: https://doi.org/10.1101/2020.03.05.20031054; this version posted March 6, 2020. The copyright holder for this preprint (which was not certified by peer review) is the author/funder, who has granted medRxiv a license to display the preprint in perpetuity.

It is made available under a CC-BY-NC-ND 4.0 International license .

26. Khera AV, Chaffin M, Aragam KG, et al. Genome-wide polygenic scores for common diseases identify individuals with risk equivalent to monogenic mutations. Nature Genetics 2018;50(9):1219-24.

27. Gibson G. Rare and common variants: twenty arguments. Nature Reviews Genetics 2012;13(2):135-45.

28. Eikelboom JW, Quinlan DJ, Douketis JD. Extended-duration prophylaxis against venous thromboembolism after total hip or knee replacement: a meta-analysis of the randomised trials. The Lancet 2001;358(9275):9-15.

29. Thomas RH. Hypercoagulability Syndromes. Archives of Internal Medicine 2001;161(20):24339.

30. Goldhaber SZ, Turpie AGG. Prevention of Venous Thromboembolism Among Hospitalized Medical Patients. Circulation [Internet] 2005 [cited 2019 Aug 21];111(1). Available from: https://www.ahajournals.org/doi/10.1161/01.CIR.0000150393.51958.54

31. Simioni P. Incidence of venous thromboembolism in asymptomatic family members who are carriers of factor V Leiden: a prospective cohort study. Blood 2002;99(6):1938-42.

32. de Haan HG, van Hylckama Vlieg A, Germain M, et al. Genome-Wide Association Study Identifies a Novel Genetic Risk Factor for Recurrent Venous Thrombosis. Circulation: Genomic and Precision Medicine [Internet] 2018 [cited 2019 Nov 1];11(2). Available from: https://www.ahajournals.org/doi/10.1161/CIRCGEN.117.001827 
medRxiv preprint doi: https://doi.org/10.1101/2020.03.05.20031054; this version posted March 6, 2020. The copyright holder for this preprint (which was not certified by peer review) is the author/funder, who has granted medRxiv a license to display the preprint in perpetuity.

It is made available under a CC-BY-NC-ND 4.0 International license .

33. Stegeman BH, de Bastos M, Rosendaal FR, et al. Different combined oral contraceptives and the risk of venous thrombosis: systematic review and network meta-analysis. BMJ 2013;347(sep12 1):f5298-f5298.

34. Hoppener MR, Kraaijenhagen RA, Hutten BA, Buller HR, Peters RJG, Levi M. Beta-receptor blockade decreases elevated plasma levels of factor VIII:C in patients with deep vein thrombosis. Journal of Thrombosis and Haemostasis 2004;2(8):1316-20.

35. Bonutti PM, Sodhi N, Patel YH, et al. Novel venous thromboembolic disease (VTED) prophylaxis for total knee arthroplasty_aspirin and fish oil. Annals of Translational Medicine 2017;5(S3):S30-S30.

36. Isaksen T, Evensen LH, Johnsen SH, et al. Dietary intake of marine n-3 polyunsaturated fatty acids and future risk of venous thromboembolism. Research and Practice in Thrombosis and Haemostasis 2019;3(1):59-69.

37. Schouten HJ, Geersing G-J, Oudega R, van Delden JJM, Moons KGM, Koek HL. Accuracy of the Wells Clinical Prediction Rule for Pulmonary Embolism in Older Ambulatory Adults. Journal of the American Geriatrics Society 2014;62(11):2136-41.

38. Gruettner J, Walter T, Lang S, et al. Importance of Wells score and Geneva score for the evaluation of patients suspected of pulmonary embolism. In Vivo 2015;29(2):269-72.

39. Silveira PC, Ip IK, Goldhaber SZ, Piazza G, Benson CB, Khorasani R. Performance of Wells Score for Deep Vein Thrombosis in the Inpatient Setting. JAMA Internal Medicine 2015;175(7):1112. 
medRxiv preprint doi: https://doi.org/10.1101/2020.03.05.20031054; this version posted March 6, 2020. The copyright holder for this preprint (which was not certified by peer review) is the author/funder, who has granted medRxiv a license to display the preprint in perpetuity.

It is made available under a CC-BY-NC-ND 4.0 International license.

40. Modi S, Deisler R, Gozel K, et al. Wells criteria for DVT is a reliable clinical tool to assess the risk of deep venous thrombosis in trauma patients. World J Emerg Surg [Internet] 2016 [cited 2019 Sep 2];11. Available from: https://www.ncbi.nlm.nih.gov/pmc/articles/PMC4898382/ 
medRxiv preprint doi: https://doi.org/10.1101/2020.03.05.20031054; this version posted March 6, 2020. The copyright holder for this preprint (which was not certified by peer review) is the author/funder, who has granted medRxiv a license to display the preprint in perpetuity.

It is made available under a CC-BY-NC-ND 4.0 International license .

Figures

Figure 1. Adjusted Hazard Ratios for Venous Thromboembolism for Established Risk Factors. Shown are the adjusted hazard ratios for venous thromboembolism for eleven established risk factors. For any individual risk factor, Cox regression models were adjusted for all other established risk factors and the first four principal components of ancestry. The I bars represent $95 \%$ confidence intervals. Body mass index $(*)$ was measured in $\mathrm{kg} / \mathrm{m}^{2}$.

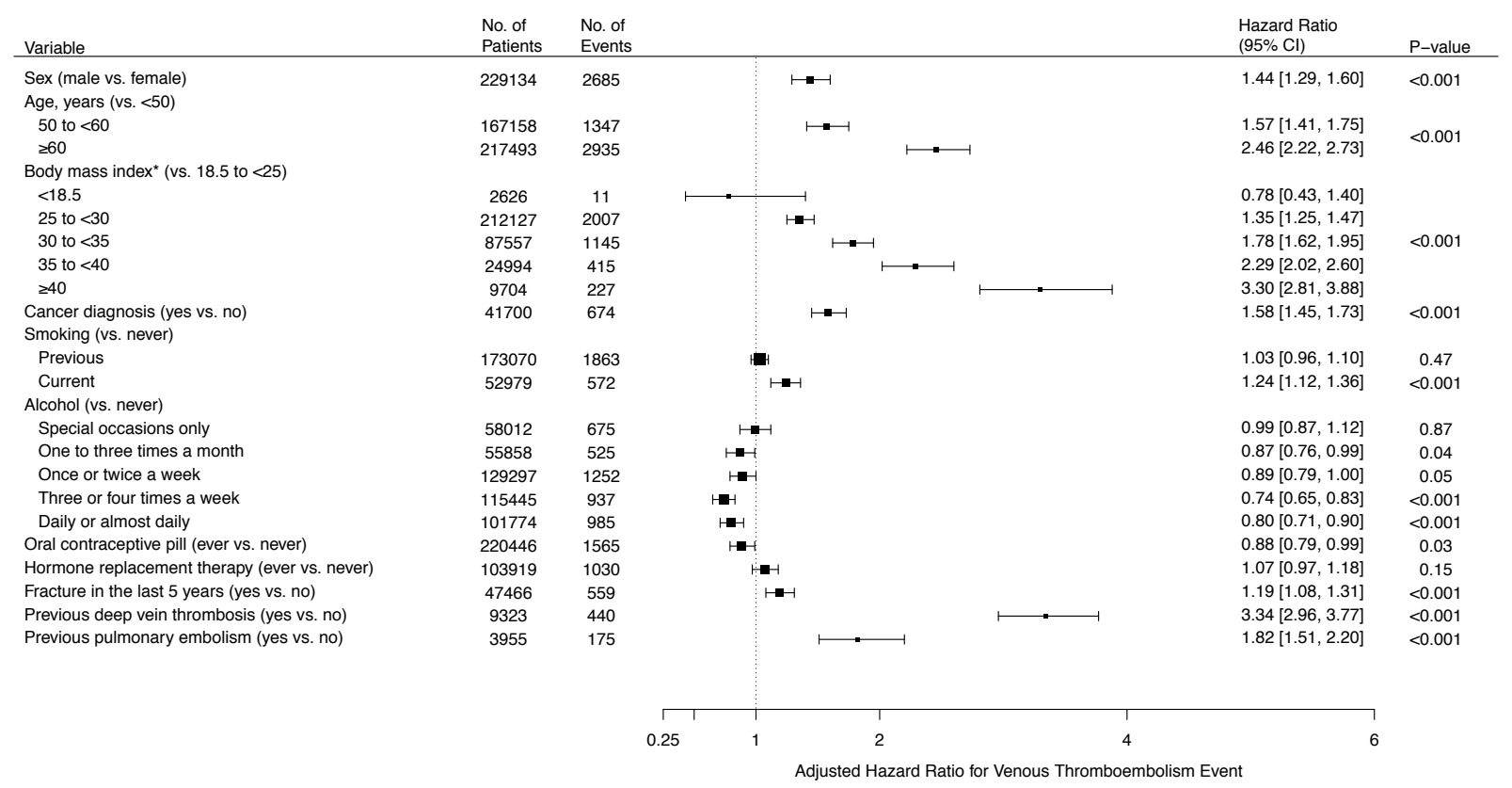


medRxiv preprint doi: https://doi.org/10.1101/2020.03.05.20031054; this version posted March 6, 2020. The copyright holder for this preprint (which was not certified by peer review) is the author/funder, who has granted medRxiv a license to display the preprint in perpetuity.

It is made available under a CC-BY-NC-ND 4.0 International license .

Figure 2. Adjusted Hazard Ratios for Venous Thromboembolism for Common Cancer Subtypes, Medications, Non-Cancer Illnesses, and Fracture Sites. Shown are the adjusted hazard ratios for venous thromboembolic events for four factors of interest: common cancer subtypes, medications, non-cancer illnesses, and fracture sites. All estimates were adjusted for all eleven established risk factors and the first four principal components of ancestry. The I bars represent $95 \%$ confidence intervals

\section{A}

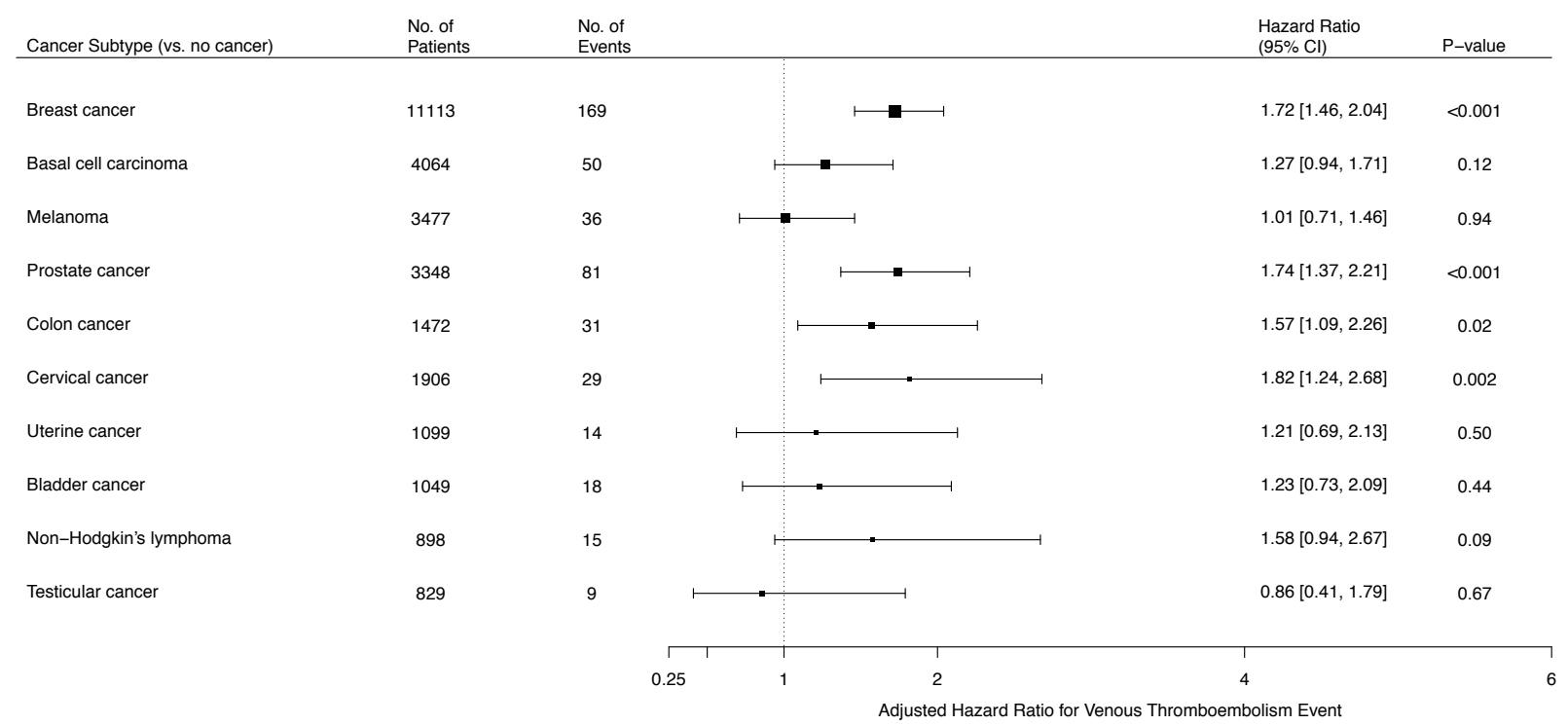

B

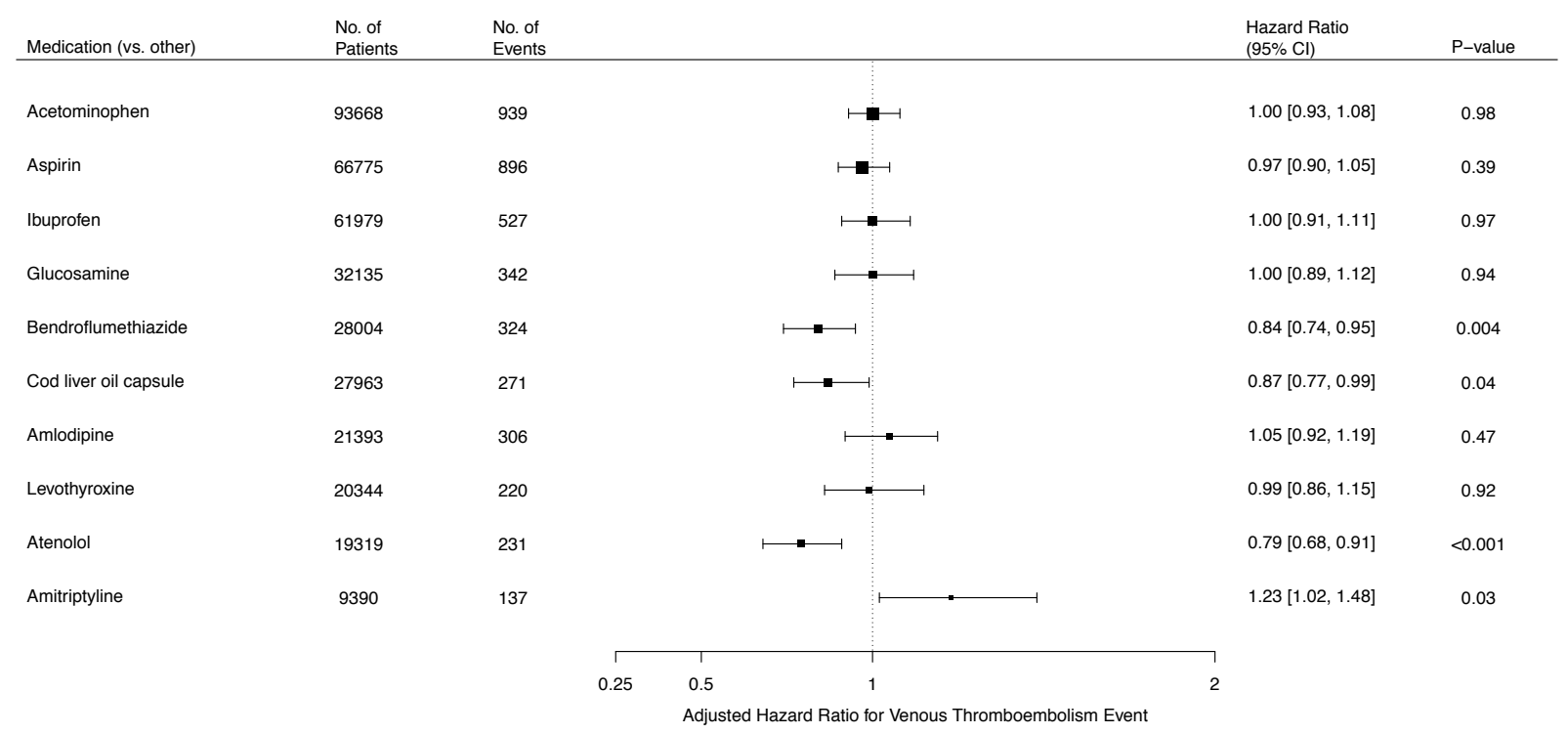


medRxiv preprint doi: https://doi.org/10.1101/2020.03.05.20031054; this version posted March 6, 2020. The copyright holder for this preprint (which was not certified by peer review) is the author/funder, who has granted medRxiv a license to display the preprint in perpetuity.

\section{It is made available under a CC-BY-NC-ND 4.0 International license .}

\section{C}

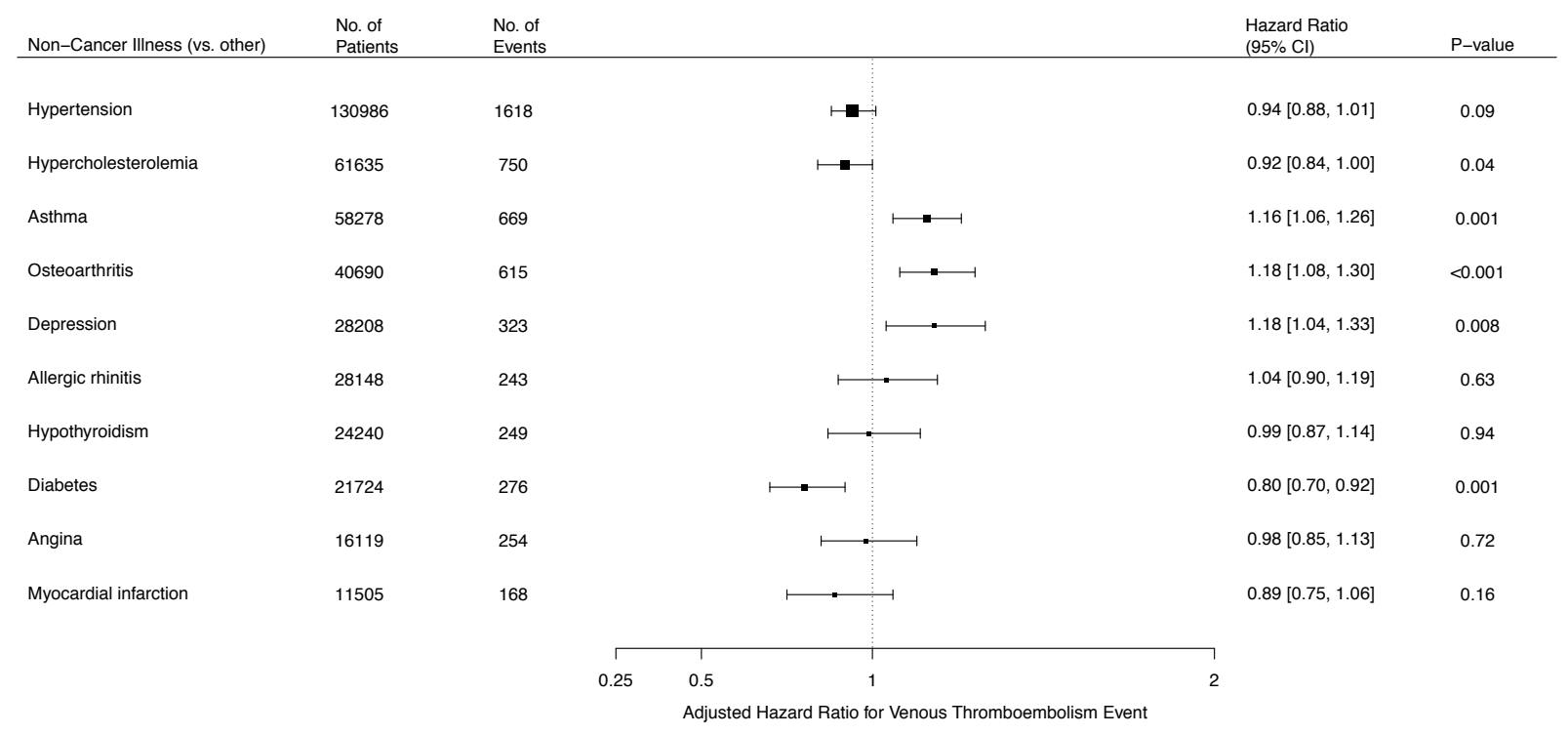

D

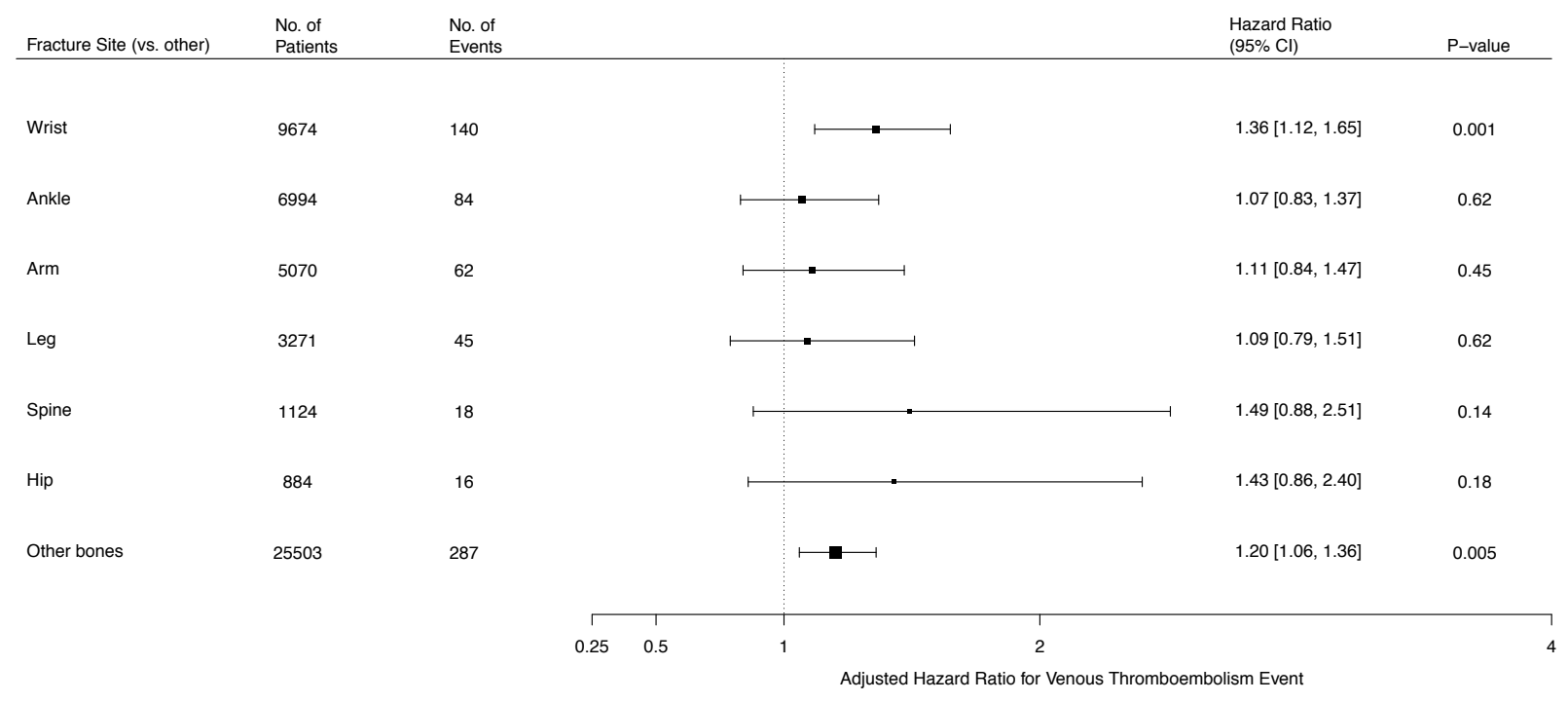


medRxiv preprint doi: https://doi.org/10.1101/2020.03.05.20031054; this version posted March 6, 2020. The copyright holder for this preprint (which was not certified by peer review) is the author/funder, who has granted medRxiv a license to display the preprint in perpetuity.

It is made available under a CC-BY-NC-ND 4.0 International license.

Figure 3. Model Performance of a Basic, Clinical, Genetic, and Combined Score. Panel A shows the density of the polygenic risk score stratified by the $50^{\text {th }}, 75^{\text {th }}, 90^{\text {th }}, 95^{\text {th }}, 99^{\text {th }}$ and $99.5^{\text {th }}$ percentiles. Panel B shows the odds ratio for each polygenic risk score percentile. Panel $\mathrm{C}$ shows the concordance values, derived from adjusted Cox-proportional hazard models, for the basic, clinical, genetic, and combined scores. The concordance of the combined model is significantly higher than the concordance of each of the other models $(\mathrm{P}<0.001)$. The I bars represent $95 \%$ confidence intervals.
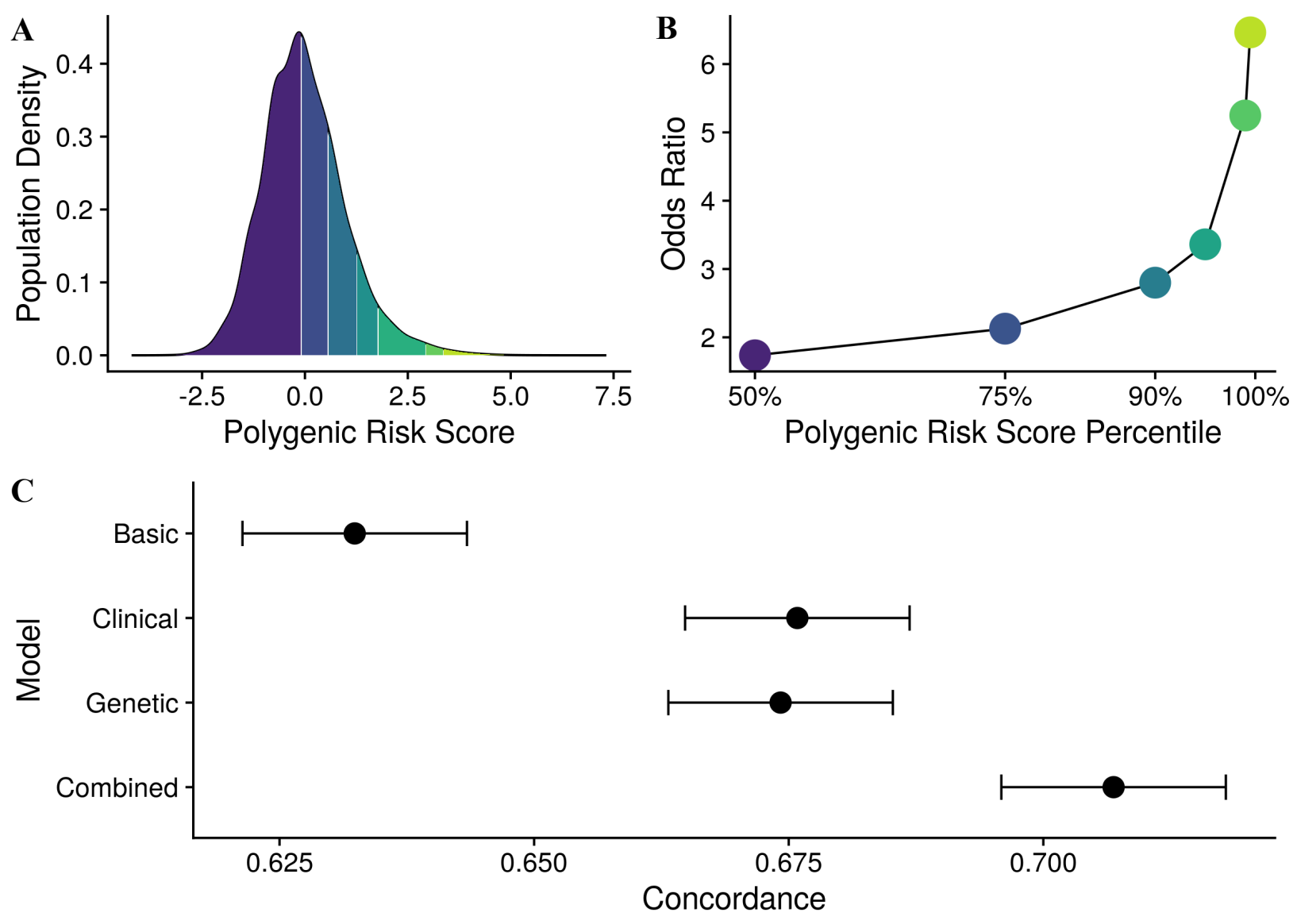
medRxiv preprint doi: https://doi.org/10.1101/2020.03.05.20031054; this version posted March 6, 2020. The copyright holder for this preprint (which was not certified by peer review) is the author/funder, who has granted medRxiv a license to display the preprint in perpetuity.

It is made available under a CC-BY-NC-ND 4.0 International license .

Figure 4. Prediction of Venous Thromboembolism. Panel A and B show the adjusted KaplanMeier curves for the genetic and clinical score, respectively. Panel $\mathrm{C}$ shows 10-year event rates for venous thromboembolism, stratified by both the clinical score and genetic score. The I bars represent $95 \%$ confidence intervals.
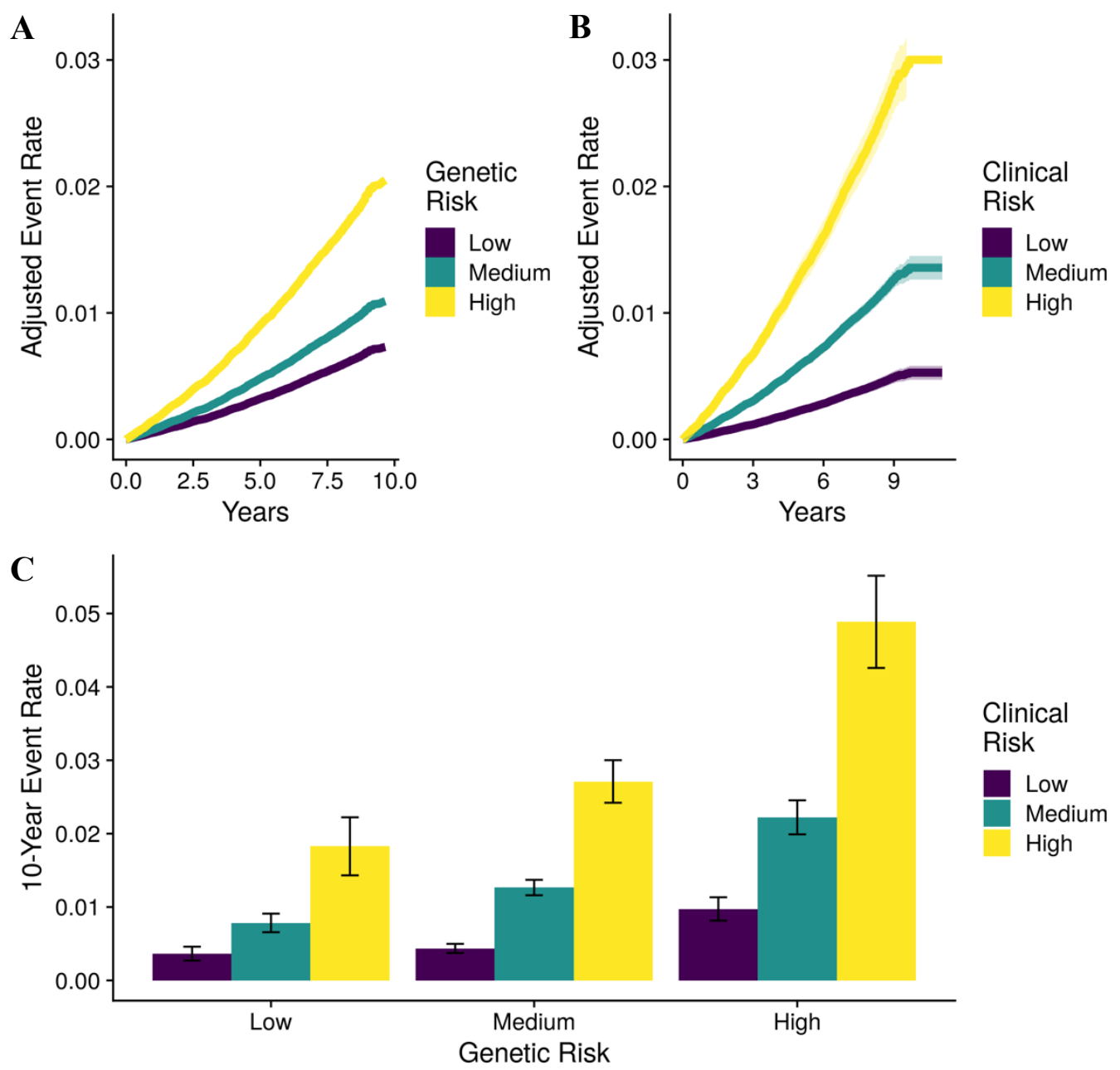

Clinical

Risk

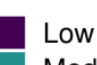

Medium

High 